http://cakrawalajournal.org/index.php/cakrawala Volume 15 Nomor 2 Desember 2021

JURกคL UTBВคกG KEBIJดKคก

Cakrawala: Jurnal Litbang Kebijakan has been accredited as a scientific journal by the Ministry of Research-Technology and Higher Education

Republic of Indonesia: No. 28/E/KPT/2019 [SINTA-5]

\title{
Uji Daya Terima dan Nilai Gizi Makanan Pendamping ASI (MPASI) Berbahan Pangan Lokal di Posyandu Wilayah Kerja Puskesmas Sidosermo Kota Surabaya
}

\author{
Yuni Prabawani \\ UPT Laboratorium Gizi Dinas Kesehatan Propinsi Jawa Timur, Indonesia
}

DOI: $10.32781 /$ cakrawala.v15i2.358

\begin{tabular}{l} 
ARTICLE INFO \\
Daya Terima, \\
Nilai Gizi, \\
MPASI, \\
Bahan Pangan Lokal. \\
\hline Article History: \\
Received : 7 Nov 2020 \\
Accepted : 6 Nov 2021 \\
Publish : 22 Des 2021
\end{tabular}

Abstrak:

Tujuan penelitian ini adalah tersusunnya 15 macam MPASI yang memenuhi syarat Gizi, mengetahui nilai gizi MPASI dan daya terimanya. Penelitian ini menggunakan metode eksperimental dengan purposive sampling dan kriteria inklusi usia 6-24 bulan, sehat dan mengikuti penimbangan di Posyandu setempat. Bahannya adalah15 MPASI@20 porsi dengan peralatan masak sesuai yang dibutuhkan dan formulir Comstok, alat tulis dan air putih untuk mengetahui daya terima panelis, yaitu bayi usia 6-8 bulan, 9-12 bulan dan >12 bulan.di 4 Posyandu lokasi penelitian. Pembuatan MPASI dilaksanakan di Laboratorium Diit UPT Laboratorium Gizi Dinas Kesehatan Provinsi Jawa Timur. Sedangkan uji daya terima dilaksanakan di 4 posyandu wilayah Puskesmas Sidosermo. Kandungan Vitamin C MPASI diuji dengan Iodometri di UPT Laboratorium Gizi dan untuk zat gizi lainnya menggunakan Nutrisurvey. Sedangkan uji daya terima menggunakan Comstok. Hasilnya diperoleh 15 resep MPASI, dengan nilai gizi tertinggi pada MP ASI umur 6-8 bulan kandungan protein tertinggi terdapat pada Bubur Batel (8 gram). Sedangkan untuk kandungan Vitamin C tertinggi pada bubur Payam (7.04 mg) dan Fe tertinggi pada Bubur Totel (1.4 mg). Kandungan Zink tertinggi $0.5 \mathrm{mg}$ pada bubur Payam, bubur Batel dan bubur Totel. MPASI kelompok usia 9-12 bulan kandungan Protein tertinggi (7.8 gram), Vitamin C tertinggi $(6.18 \mathrm{mg})$, Fe tertinggi $(2.3 \mathrm{mg}) \mathrm{dan}$ Zink (1.2 mg) tertinggi ada pada bubur Bijay. MP ASI kelompok usia $>12$ bulan kandungan energi( $212 \mathrm{kcal})$, protein (9.5 gram), lemak (23 gram) dan vitamin $C(17,6 \mathrm{mg})$ tertinggi terkandung pada menu nasi, Nugget Lele, Mendol Tempe, Sayur Kelor Wortel. Penggunaan bahan pangan lokal berbagai jenis ikan dan sayuran pada pembuatan MPASI ini menciptakan MP ASI dengan nilai gizi yang tinggi baik dari kandungan protein, Fe, Zink dan vitamin $C$ sehingga sangat bagus untuk meningkatkan asupan protein, $\mathrm{Fe}$, Zink dan Vitamin C alamiah untuk anak 6-24 bulan. MPASI yang paling disukai adalah krupuk pangsit udang 75\% habis terkonsumsi (15 panelis), dan yang paling tidak disukai adalah bubur Bijay utuh 100\% (1 panelis). Kesimpulannya MPASI yang dihasilkan adalah 10 resep makanan utama dan 5 resep makanan selingan, berbahan pangan lokal mengandung zat gizi energi, protein, Fe, Zink dan Vitamin C yang tinggi dan dapat diterima oleh panelis, diantaranya adalah Burikli, Bujasay dan nasi nugget Lele mendol tempe sayur kelor wortel.

Corresponding author:

Address $\quad$ : Jl. Bendul Merisi No.126, Bendul Merisi, Kec. Wonocolo, Kota SBY, Jawa Timur 60239

Hal. 153-162

Emai p-ISSN 1978-0354 | e-ISSN 2622-013X 
PENDAHULUAN

Pemberian makanan yang sesuai dan sehat bagi bayi pada tahun pertama kehidupan sangatlah penting. Diawali dengan hanya pemberian Air Susu Ibu (ASI) saja sampai umur 6 bulan, kemudian dilanjutkan dengan Makanan Pendamping ASI (MP ASI) yang berkualitas adalah hal utama yang harus diperhatikan setiap Ibu. Karena pada usia pertama kehidupan terjadi pertumbuhan dan perkembangan otak yang pesat disamping itu kebiasaan makan yang baik pada tahap awal akan membantu membentuk pola makan yang baik pada usia selanjutnya.

Gizi bayi yang baik berarti memastikan bayi mendapat cukup nutrisi selama tahun pertamanya. Gizi adalah terdiri dari energi, protein, lemak, vitamin, dan mineral. Untuk mencapai tumbuh kembang optimal orangtua harus memastikan bayi memperoleh asupan gizi yang baik dapat melindungi dirinya terhadap penyakit. Hal ini juga membantu bayi tetap sehat pada saat ia tumbuh sesuai dengan pertumbuhan yang normal di kemudian hari.

Era sekarang ibu - ibu muda lebih sering membeli MP ASI dari pada membuat sendiri, karena ingin praktis dan tidak repot, tanpa memikirkan kualitas dari makanan tersebut. Selain itu pemberian MP ASI pada tahap awal sering kali hanya terdiri dari tepung beras dengan santan dan gula saja tanpa adanya sumber protein dan sayur, atau bahkan hanya berupa buah saja. Ada pula kepercayaan masyarakat Jawa Timur yang melarang untuk memberikan lauk hewani pada bayi usia $6-11$ bulan. Hal ini tidak sesuai dengan anjuran dari WHO, dimana untuk pemberian MP ASI pada tahap awal harus mengandung Zat Gizi yang proporsional. Karena pada tahap awal ini terjadi pertumbuhan dan perkembangan otak yang cepat. Disamping komposisi zat Gizi yang harus proporsional, perlu juga diperhatikan konsistensi serta osmolaritas dari makanan tersebut.
Penggunaan bahan pangan lokal berupa ikan, ayam, telur, umbi-umbian, kacang-kacangan, sayuran dan buah-buahan yang bergizi, murah dan mudah diperoleh disekitar kita dapat melengkapi komposisi gizi MP ASI agar bayi memperoleh asupan gizi yang optimal. Sehingga variasi MPASI dengan pangan lokal perlu terus diupayakan sehingga MP ASI lebih beragam seimbang dan menyehatkan bayi.

Kekurangan zat Gizi pada tahap awal pertumbuhan akan menghambat pertumbuhan dan perkembangan anak, sehingga anak menjadi Stunting (kurang Gizi kronik).Untuk mengatasi hal tersebut perlu diformulasikan Makanan Pendamping ASI (MP ASI) yang padat Zat Gizi dengan konsistensi dan Osmolaritas yang sesuai untuk bayi.

\section{METODE PENELITIAN}

Penelitian ini menggunakan metode eksperimental dengan tehnik pengambilan sampel purposive sampling dengan kriteria inklusi Balita usia 6-24 bulan, sehat dan mengikuti penimbangan di Posyandu setempat. Bahan 15 macam MP ASI yang terbagi dalam 3 MP ASI sesuai kelompok umur 6-8 bulan dengan pangan lokal ikan Tongkol, Patin, Bandeng, Lele, tempe, tahu, kentang, daun kelor, bayam, wortel, brokoli, labu kuning. Kelompok umur 9-12 bulan dengan pangan lokal ikan Patin, Mujair, hati ayam, telur, ayam, tempe, ubi kuning, jagung manis, labu kuning, bayam, buncis, kangkung, wortel, sawi daging dan buah naga. Kelompok umur $>$ 12 bulan dengan pangan lokal ikan Lele, Tongkol, Patin, udang, telur, Keju, tempe, tahu, Kacang hijau, daun kelor, sawi daging, wortel, buncis, labu kuning dan pisang kepok. Bahan yang terdapat di 15 resep tersebut kemudian dimasak menjadi produk MPASI@20 porsi. Adapun alat yang digunakan adalah peralatan masak sesuai yang dibutuhkan dalam resep 
tersebut dan formulir Comstok, alat tulis dan air putih untuk mengetahui daya terima panelis terhadap MP ASI. Panelis tidak terlatih, yaitu bayi usia 6-8 bulan, bayi usia 9-12 bulan dan balita usia $>12$ bulan di 4 Posyandu lokasi penelitian. Setiap panelis melakukan uji daya terima dari 1 resep MPASI sesuai dengan kelompok usianya. Lokasi penelitian untuk pembuatan MPASI di Laboratorium Diit UPT Laboratorium Gizi Dinas Kesehatan Provinsi Jawa Timur. Sedangkan untuk uji organoleptik dilaksanakan di posyandu wilayah Puskesmas Sidosermo yaitu Posyandu Kenanga 2, Posyandu Anggrek 1, Posyandu Kasih Bunda dan Posyandu Dahlia 4, dimana Posyandu terpilih ditentukan oleh petugas Gizi Puskesmas Sidosermo dengan asumsi posyandu tersebut mempunyai anggota sejumlah balita $>50$ anak. Di setiap Posyandu dilakukan uji tingkat kesukaan mengggunakan metode comstock yaitu dengan mengamati dan memperkirakan sisa dari yang terkonsumsi. Dengan katagori:
a. Habis termakan
b. Sisa $\leq 50 \%$
c. Sisa $>50 \%$.

Untuk mengetahui nilai gizi MP ASI terbagi menjadi 2 cara, yaitu uji kandungan Vitamin $\mathrm{C}$ pada MP ASI dengan menggunakan uji Iodometri di Laboratorium UPT Laboratorium Gizi dan untuk zat gizi yang lainnya dalam MP ASI dengan menggunakan alat bantu Nutrisurvey.

Pelaksanaan pembuatan resep MP ASI tanggal 15-16 Januari 2020 dan tanggal 4 Februari untuk uji coba resep MP ASI. Sedangkan tanggal 12 Februari 2020 membuat MP ASI dan uji organoleptik.

Sampel yang digunakan untuk uji organoleptic adalah MP ASI sebanyak 15 resep@20 porsi yang terdiri dari MP ASI untuk usia 6-8 bulan (5 resep), MP ASI untuk usia 9-12 bulan (5 resep) dan MP ASI untuk usia $>12$ bulan (5 resep). Sedangkan untuk pengadaan bahan pembuatan resep dibeli di pasar Mangga Dua Surabaya.

Adapun variabel bebas dalam penelitian ini adalah MP ASI. Variabel terikatnya adalah nilai gizi MP ASI dan daya terima MP ASI. Untuk definisi operasional dari MP ASI adalah makanan pendamping ASI yang telah disusun

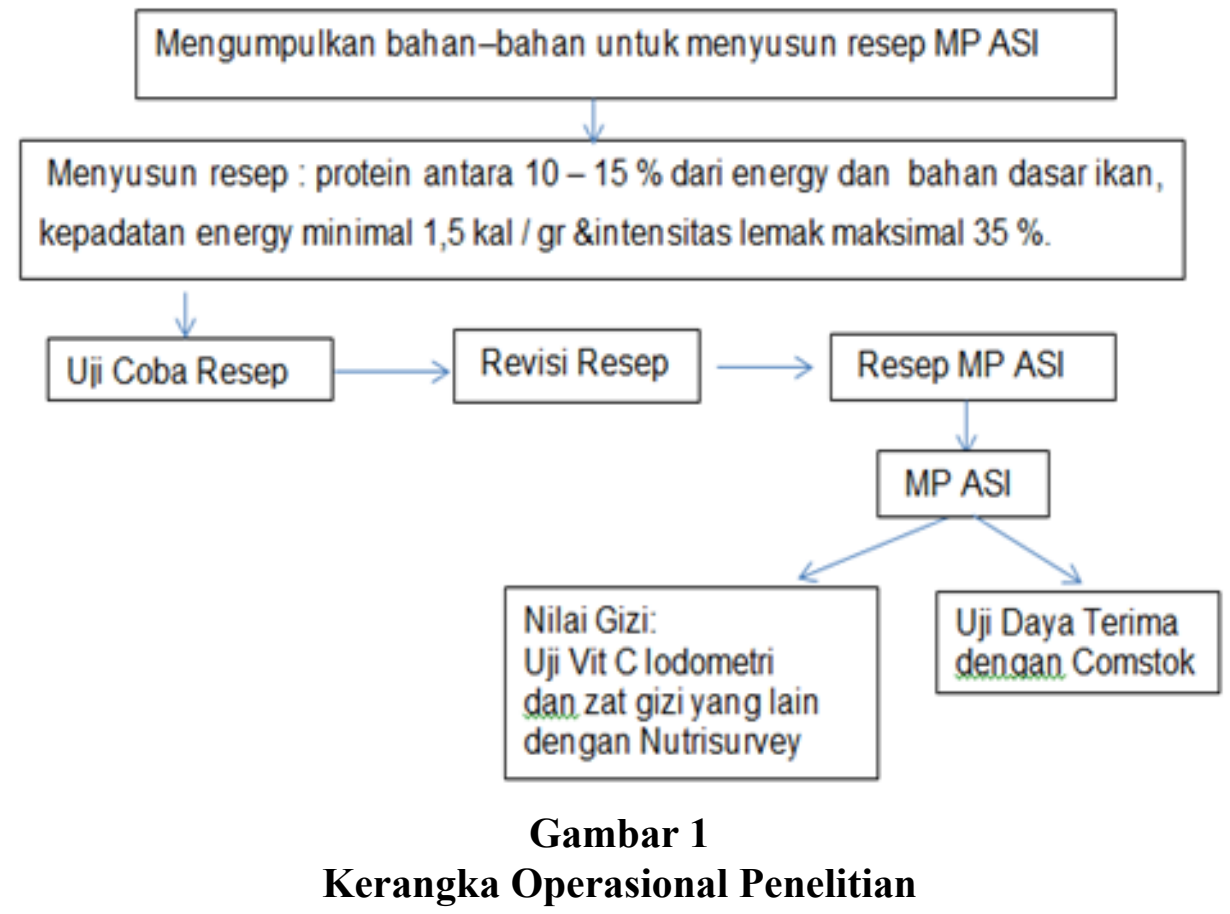


sesuai dengan kebutuhan energi dan zat gizi untuk usia 6-8 bulan, 9-12 bulan dan usia $>12$ bulan dengan prosentase protein antara $10-15 \%$ dari energi dan bahan dasar ikan, serta dengan kepadatan energy minimal 1,5 kal / gr dan intensitas lemak maksimal $35 \%$. Sedangkan nilai gizi MPASI adalah nilai gizi Vitamin $\mathrm{C}$ yang terkandung di dalam MP ASI dengan menggunakan uji Iodometri dan zat gizi lainnya dengan menggunakan alat bantu nutrisurvey. Untuk daya terima adalah tingkat penerimaan MP ASI oleh panelis dilihat dari sisa MP ASI yang terkonsumsi dengan klasifikasisebagai berikut:
a. Habis $(0 \%)$
b. Sisa $\leq 50 \%$
c. Sisa $>50 \%$.

\section{HASIL DAN PEMBAHASAN}

Resep MP ASI yang disusun adalah resep MP ASI berbahan pangan lokal, bergizi seimbang dengan prosentase protein antara $10-15 \%$ dari energi dan bahan dasar ikan, serta dengan kepadatan energy minimal 1,5 $\mathrm{kal} / \mathrm{gr}$. Intensitas lemak maksimal $35 \%$. MP ASI ini terdiri dari MP ASI untuk usia 6-8 bulan berupa makanan utama 5 macam, MP ASI usia 9-12 bulan berupa makanan utama 3 macam dan kudapan 2 macam serta MP ASI untuk usia $>12$ bulan berupa makanan utama 2 macam dan kudapan 3 macam.

\section{Resep MP ASI}

Adapun resep MP ASI yang dihasilkan sebanyak 15 resep dengan rincian sebgai berikut:

Untuk kelompok usia 6 - 8 bulan:
a. Bubur Patin Bayam (Payam)
b. Bubur Batel
c. Bubur Kelamuj
d. Brokoli
e. Bubur Totel

Untuk kelompok usia 9 - 12 bulan:
a. Bubur Latin
b. Bubur Bijay
c. Bujasay
d. Bolu Kukus Buah Sayur
e. Green Talam

Untuk kelompok usia diatas 12 bulan:

a. Menu nasi, Nugget Lele, Mendol Tempe, sayur Kelor Wortel

b. Nasgultin

c. Krupuk Pangsit Udang

d. Puding Roti Pisang

e. Stick Labu Krees

Untuk 5 MP ASI usia 6-8 bulan semuanya berupa makanan lengkap yang dijadikan dalam satu sajian yang terdiri dari sumber karbohidrat, lauk hewani, lauk nabati dan sayuran dengan bentuk makanan bubur.

Sedangkan MP ASI untuk usia 9-12 bulan terdapat 3 macam berupa makanan lengkap dalam satu sajian yang terdiri dari sumber karbohidrat, lauk hewani, lauk nabati dan sayuran dengan bentuk makanan bubur dan 2 macam kudapan yaiti bolu dan talam.

Untuk MP ASI usia $>12$ bulan terdapat 1 macam berupa makanan lengkap dalam satu sajian yang terdiri dari sumber karbohidrat, lauk hewani, lauk nabati dan sayuran dengan nasi yang digulung. Dan 1 macam makanan hidangan lengkap seperti menu keluarga ada nasi lauk hewani, lauk nabati dan sayuran. Selain itu ada 3 macam MP ASI berupa kudapan, yaitu Krupuk Pangsit Udang, Puding Roti Pisang dan Stick Labu Krees. Adapun resep secara rinci terlampir.

\section{Nilai Gizi MP ASI}

Untuk melihat nilai gizi dari MP ASI ke 15 resep yang ada menggunakan uji Iodometri untuk Vitamin $\mathrm{C}$ dan dengan alat bantu nutrisurvey untuk mengetahui nilai gizi yang lain pada MP ASI. Adapun nilai Gizi dari 15 macam MP ASI yang dapat dilihat pada Tabel 1, 2 dan 3.

Dari tabel 1, 2, dan 3 dapat dilihat bahwa nilai gizi MP ASI per kelompok umur semakin banyak usianya maka nilai 
gizi yang terdapat di dalam MP ASI juga semakin tinggi.

Pada MP ASI kelompok umur 6-8 bulan kandungan energi( $86.13 \mathrm{kcal})$ dan lemak (3.49 gram) tertinggi terkandung dalam Burikli. Untuk Protein tertinggi terdapat pada Bubur Batel (8 gram). Sedangkan untuk kandungan Karbohidrat tertinggi ada pada Bubur Totel (11.29 gram) dan vitamin $\mathrm{C}$ tertinggi ada pada bubur Payam (7.04 mg), untuk kandungan Fe tertinggi ada pada Bubur Totel $(1.4 \mathrm{mg})$. Kandungan Zink tertinggi $0.5 \mathrm{mg}$ ada pada bubur Payam, bubur Batel dan bubur Totel.

Pada MP ASI kelompok usia 9-12 bulan kandungan energi( 118.7 kcal $)$ tertinggi, lemak tertinggi (7 gram) dan karbohidrat tertinggi (15.7 gram). terkandung dalam Bujasay. Untuk Protein tertinggi (7.8 gram), Vitamin $\mathrm{C}$ tertinggi
(6.18 mg), Fe tertinggi $(2.3 \mathrm{mg})$ dan Zink (1.2 mg) tertinggi ada pada bubur Bijay.

Pada MP ASI kelompok usia $>12$ bulan kandungan energi $(212 \mathrm{kcal})$, protein (9.5 gram), lemak (23 gram) dan vitamin C (17,6 mg) tertinggi terkandung pada menu nasi, Nugget Lele, Mendol Tempe, Sayur Kelor Wortel. Sedangkan kandungan lemak tertinggi ada pada Steik Labu Kress (11 gram). Kandungan tertinggi $\mathrm{Fe}(3.13 \mathrm{mg})$ pada Nasgutin dan Zink (1.2 mg) tertinggi ada pada Krupuk Pangsit Udang.

Penggunaan bahan pangan lokal berbagai jenis ikan dan sayur pada pembuatan MP ASI ini ternyata mampu menciptakan MP ASI dengan nilai gizi yang tinggi baik dari kandungan protein, Fe, Zink dan Vitamin $\mathrm{C}$ sehingga sangat bagus untuk meningkatkan asupan protein, Fe, Zink dan Vitamin $\mathrm{C}$ yang alamiah untuk anak usia $6-24$ bulan.

Tabel 1. Nilai Gizi MP ASI Usia 6-8 bulan Berbahan Pangan Lokal

\begin{tabular}{llccccccc}
\hline No & Menu & \multicolumn{7}{c}{ Nilai Gizi } \\
\cline { 3 - 10 } & Energi & $\mathbf{P}$ & $\mathbf{K H}$ & $\mathbf{L}$ & Vit C & $\mathbf{F e}$ & $\mathbf{Z n}$ \\
\cline { 3 - 10 } & MP ASI Usia 6-8 bulan & Kcal & $\mathbf{( g r )}$ & $\mathbf{( g r )}$ & $\mathbf{( g r )}$ & $\mathbf{( m g )}$ & $\mathbf{( m g )}$ & $\mathbf{( m g )}$ \\
\hline 1 & Bubur Payam & 75.23 & 7.47 & 5.63 & 2.84 & 7.04 & 1 & 0.5 \\
\hline 2 & Bubur Batel & 77.48 & 8 & 6.46 & 2.39 & 5.28 & 0.8 & 0.5 \\
\hline 3 & Bubur Kelamuj & 78.45 & 7.32 & 6.34 & 2.76 & 6.6 & 1.3 & 0.4 \\
\hline 4 & Burikli & 86.13 & 6.72 & 7.13 & 3.49 & 6.16 & 0.4 & 0.2 \\
\hline 5 & Bubur Totel & 78.9 & 6.27 & 11.29 & 1.18 & 4.4 & 1.4 & 0.5 \\
\hline
\end{tabular}

Sumber: Data Diolah (2021)

Tabel 2. Nilai Gizi MP ASI Usia 9-12 bulan Berbahan Pangan Lokal

\begin{tabular}{llccccccc}
\hline No & Menu & \multicolumn{7}{c}{ Nilai Gizi } \\
\cline { 3 - 9 } & Energi & $\mathbf{P}$ & $\mathbf{K H}$ & $\mathbf{L}$ & $\mathbf{V i t} \mathbf{C}$ & $\mathbf{F e}$ & $\mathbf{Z n}$ \\
\cline { 3 - 9 } & MP ASI Usia 9-12 bulan & Kcal & $\mathbf{( g r )}$ & $\mathbf{( g r )}$ & $\mathbf{( g r )}$ & $\mathbf{( m g )}$ & $\mathbf{( m g )}$ & $\mathbf{( m g )}$ \\
\hline 1 & Bubur Latin & 116 & 4.8 & 10.6 & 6.3 & 4.4 & 0.4 & 0.3 \\
\hline 2 & Bubur Bijay & 100 & 7.8 & 10.8 & 7 & 6.16 & 2.3 & 1.2 \\
\hline 3 & Bujasay & 118.7 & 5.8 & 15.7 & 3.6 & 3.52 & 0.4 & 0.4 \\
\hline 4 & $\begin{array}{l}\text { Bolu kukus Buah } \\
\text { Sayur }\end{array}$ & 66.85 & 1.95 & 9.35 & 2.35 & 5.28 & 0.45 & 0.187 \\
\hline 5 & Green Talam & 74.09 & 2.2 & 9.8 & 2.8 & 3.96 & 0.24 & 0.22 \\
\hline
\end{tabular}

Sumber: Data Diolah (2021) 
Tabel 3. Nilai Gizi MP ASI Usia $>12$ bulan Berbahan Pangan Lokal

\begin{tabular}{|c|c|c|c|c|c|c|c|c|}
\hline \multirow[t]{2}{*}{ No } & \multirow[t]{2}{*}{ Menu } & \multicolumn{7}{|c|}{ Nilai Gizi } \\
\hline & & Energi & $\mathbf{P}$ & KH & $\mathbf{L}$ & Vit C & $\mathrm{Fe}$ & $\mathbf{Z n}$ \\
\hline \multicolumn{2}{|c|}{$\begin{array}{l}\text { MP ASI Usia }>12 \\
\text { bulan }\end{array}$} & Kcal & (gr) & (gr) & (gr) & (mg) & (mg) & (mg) \\
\hline 1 & $\begin{array}{l}\text { Nasi, nugget lele, } \\
\text { Mendol Tempe, } \\
\text { Sayur Kelor } \\
\text { Wortel }\end{array}$ & 212 & 9.5 & 23 & 9.5 & 17.6 & 1.4 & 1 \\
\hline 2 & Nasgultin & 161 & 7 & 70 & 5 & 5.28 & 3.13 & 0.7 \\
\hline 3 & $\begin{array}{l}\text { Kerupuk Pangsit } \\
\text { Udang }\end{array}$ & 165 & 5 & 22 & 6 & 4.4 & 1.3 & 1.3 \\
\hline 4 & $\begin{array}{l}\text { Puding Roti Pi- } \\
\text { sang }\end{array}$ & 118 & 3 & 19 & 4 & 5.28 & 0.6 & 0.6 \\
\hline 5 & Stick Labu Kress & 180 & 4 & 16 & 11 & 5.28 & 0.6 & 0.3 \\
\hline
\end{tabular}

Sumber: Data Diolah (2021)

Salah satu mineral yang memiliki peran penting dalam proses tumbuh kembang bayi adalah zat besi (Fe). Zat besi adalah suatu zat dalam tubuh manusia yang erat dengan ketersediaan jumlah darah yang diperlukan. Dalam tubuh manusia zat besi memiliki fungsi yang sangat penting, yaitu untuk mengangkut oksigen dari paruparu ke jaringan dan mengangkut electron di dalam proses pembentukan energi di dalam sel.Dikatakan penting sebab zat besi diperlukan tubuh untuk membentuk hemoglobin, yakni pigmen dalam darah yang bertugas mengangkut oksigen. Jika kebutuhan zat besi pada bayi tidak tercukupi, maka jumlah sel darah merah akan berkurang dan jaringan-jaringan tubuh akan menerima oksigen lebih sedikit dari standar kebutuhan. Akibatnya bayi beresiko terkena anemia yang gejalanya ditandai dengan lemah, lesu dan hilangnya napsu Di tahun pertamanya, bayi memerlukan zat besi dua kali lipat lebih banyak. Kebutuhan ini bisa dicukupi dari ASI yang diminum oleh bayi pada enam bulan pertamanya. Selanjutnya, ASI tidak lagi mampu mencukupi kebutuhan zat besi, karena itulah bayi berusia enam bulan wajib diberi MPASI, terutama bagi bayi prematur atau bayi dengan berat badan rendah. Bayi membutuhkan asupan zat besi sekitar 7-8 mg setiap harinya. Untuk mencapai angka ini tentu saja tidak mudah. Orang tua harus benar-benar memperhatikan menu makanannya serta memastikan bayi makan makanan yang mengandung cukup zat besi di dalamnya.

Dari hasil penelitian ini, 15 macam MP ASI sudah diketahui kandungan $\mathrm{Fe}$ nya. Untuk balita usia $>12$ bulan sudah dapat terpenuhi kebutuhan $\mathrm{Fe}$ nya jika mengkonsumsi Nasgultin $1 \mathrm{x}$ sehari $(\mathrm{Fe}=$ $3.13 \mathrm{mg}$ ) dan nasi, nugget lele, mendol tempe, sayur kelor, wortel $2 \mathrm{x}$ sehari $(\mathrm{Fe}=$ 2,8 mg) dengan kudapan Krupuk pangsit udang 1 porsi ( $\mathrm{Fe}=1,3 \mathrm{mg}$ ) dan puding roti pisang $(\mathrm{Fe}=0.6 \mathrm{mg})$ beserta ASI.

Jika pemenuhan $\mathrm{Fe}$ pada balita tidak terpenuhi, maka balita akan kekurangan zat besi yang juga berpengaruh pada kecerdasan, tingkah laku serta perkembangan motoriknya. Bahkan, anak yang kekurangan zat besi dampaknya akan terlihat saat ia dewasa.

Protein merupakan komponen penting dari setiap sel dalam tubuh. Protein merupakan zat pembangun yang dibutuhkan tubuh kita, diantaranya 
diperlukan dalam pembentukan tulang, otot, tulang rawan, kulit, dan darah. Untuk membangun, memperkuat, dan memperbaiki atau mengganti jaringan tubuh. Untuk membantu tubuh merasa kenyang lebih lama. Untuk membuat hormon yang berfungsi membantu sel mengirim pesan dan mengkoordinasikan fungsi sel dan organ di dalam tubuh. Untuk membuat antibodi untuk sistem kekebalan tubuh. Untuk pertumbuhan dan perkembangan anak-anak, remaja, hingga wanita hamil dan janin yang dikandungnya. Untuk membuat enzim yang berfungsi memfasilitasi reaksi biokimiawi dan metabolisme tubuh. Dan untuk mengangkut sel atau zat gizi, contohnya hemoglobin yang membawa oksigen melalui darah ke seluruh tubuh.

Sumber protein dapat diperoleh dari hewani dan nabati. Adapun sumber protein diantaranya dari:

a. Makanan laut atau boga bahari Makanan laut memiliki kandungan protein yang tinggi, dan biasanya rendah lemak. Beberapa jenis makanan laut, seperti ikan salmon, juga kaya akan asam lemak omega-3 yang sangat baik untuk kesehatan jantung.

b. Susu, keju, yoghurt. Selain menjadi sumber protein yang baik, susu dan produk olahan susu juga mengandung kalsium dan vitamin D yang berfungsi menjaga kekuatan tulang dan gigi, serta mencegah osteoporosis.

c. Daging. Disarankan untuk memilih daging putih (ayam, ikan) tanpa kulit, dibandingkan daging merah (sapi, kambing). Ini karena daging merah mengandung lebih banyak lemak.

d. Telur. Bahan makanan yang terjangkau dan bergizi. Tak hanya tinggi protein, telur ayam juga mengandung vitamin B, folat, selenium, dan kolin.

e. Kacang-kacangan. Selain bergizi, kacang juga kaya akan serat yang bisa membuat kita merasa kenyang lebih lama. Kacang kedelai baik bagi jantung karena dapat membantu menurunkan kolesterol.

Protein dari sumber hewani disebut protein lengkap karena mengandung sembilan asam amino esensial. Sedangkan protein nabati dianggap tidak lengkap karena tidak memiliki satu atau lebih asam amino esensial.

AngkaKecukupan Gizi(AKG) Protein yang dibutuhkan berdasarkan Peraturan Menteri Kesehatan Republik Indonesia No. 75 Tahun 2013 tentang Angka Kecukupan Gizi yang Dianjurkan untuk balita sebesar 18 - 35 gram per hari. Pemenuhan kebutuhan protein balita bisa diperoleh dari MP ASI tersebut di atas dan ASI. Sebagai contoh kebutuhan bayi 6-8 bulan dapat tercukupi dengan mengkonsumsi bubur Payam, bubur Batel, Bubur Kelamuj dan ASI. Karena kandungan protein dari 3 macam bubur tersebut mencapai 22.79 gr dan kekurangannya bisa dipenuhi dari kandungan protein ASI (Tabel 4).

Adapun jenis ikan yang digunakan dalam pembuatan MP ASI ini diantaranya adalah ikan Lele, Tongkol, Mujair, Patin, Udang dan Bandeng. Selain ikan ada juga sumber protein dari ayam, hati

Tabel 4. Menu MP ASI Kandungan Protein untuk Bayi 6-8 bulan

\begin{tabular}{llc}
\hline No & Menu MP ASI & Protein $(\mathbf{g})$ \\
\hline 1 & Bubur Payam & 7.47 \\
\hline 2 & Bubur Batel & 8.00 \\
\hline 3 & Bubur Kelamuj & 7.32 \\
\hline Jumlah & & 22.79
\end{tabular}

Sumber: Data Diolah (2021) 
ayam,telur, susu, keju, tahu dan tempe. Disamping dapat meningkatkan protein, Fe dan Zinc, penggunaan bahan lokal berupa sayuran yang ditambahkan dalam MP ASI ini meningkatkan kandungan vitamin $\mathrm{C}$ yang sangat bermanfaat untuk meningkatkan daya tahan tubuh anak terhadap penyakit infeksi sehingga anak tidak mudah sakit dan makanan yang dikonsumsi dapat semaksimal mungkin untuk pertumbuhannya dan akhirnya akan terhindar dari stunting. Adapun jenis sayuran lokal yang digunakan adalah wortel, kelor, labu kuning, bayam, brokoli, kangkung, baby buncis dan sawi daging.

\section{Uji Daya Terima}

Hasil Uji daya terima MP ASI dilaksanakan pada tanggal 12 Februari 2020 di 4 posyandu yaitu posyandu Kenanga 2, Posyandu Anggrek 1, Posyandu Kasih Bunda dan
Posyandu Dahlia 4. Pelaksanaannya dilakukan secara bersamaan karena bulan Februari ini adalah bulan timbang, sehingga posyandu buka serentak pada tanggal tersebut. Adapun hasil uji daya yang diterima dapat dilihat pada Tabel 5 .

Tabel 5 dapat dilihat bahwa MP ASI untuk usia 6-8 bulan terdiri dari 5 macam makanan utama, dimana yang paling disukai balita usia 6-8 bulan adalah bubur Payam dan bubur Batel dan yang tidak disukai adalah bubur Totel.

Pada tabel 6 dapat dilihat bahwa MP ASI untuk usia 9-12 bulan terdiri dari 3 macam makanan utama dan 2 makanan selingan/kudapan, dimana yang paling disukai balita usia 9-12 bulan adalah Bubur Latin 50\% ( 4 panelis) dan yang tidak disukai adalah bubur Bijay sisanya 100\% (tidak terkonsumsi oleh 1 panelis).

Tabel 5. Hasil Uji Daya Terima MP ASI Usia 6-8 bulan Berbahan Pangan Lokal

\begin{tabular}{|c|c|c|c|c|c|c|c|c|}
\hline \multirow{3}{*}{ No } & \multirow{3}{*}{ Menu } & \multicolumn{7}{|c|}{ Hasil Uji Daya Terima } \\
\hline & & \multicolumn{2}{|c|}{ Habis } & \multicolumn{2}{|c|}{ Sisa $\leq 50 \%$} & \multicolumn{2}{|c|}{ Sisa $>50 \%$} & \multirow{2}{*}{ Total (n) } \\
\hline & & $\mathbf{n}$ & $\%$ & $\bar{n}$ & $\%$ & $\mathbf{n}$ & $\%$ & \\
\hline 1 & Bubur Payam & 3 & $30 \%$ & 3 & $30 \%$ & 4 & $40 \%$ & 10 \\
\hline 2 & Bubur Batel & 3 & $30 \%$ & 3 & $30 \%$ & 4 & $40 \%$ & 10 \\
\hline 3 & Bubur Kelamuj & 1 & $17 \%$ & 2 & $33 \%$ & 3 & $50 \%$ & 6 \\
\hline 4 & Burikli & 2 & $25 \%$ & 4 & $50 \%$ & 2 & $25 \%$ & 8 \\
\hline 5 & Bubur totel & 0 & $0 \%$ & 0 & $0 \%$ & 0 & $0 \%$ & 0 \\
\hline
\end{tabular}

Sumber: Data Diolah (2021)

Tabel 6. Hasil Uji Daya Terima MP ASI Usia 9-12 bulan Berbahan Pangan Lokal

\begin{tabular}{|c|c|c|c|c|c|c|c|c|}
\hline \multirow{3}{*}{ No } & \multirow{3}{*}{ Menu } & \multicolumn{7}{|c|}{ Hasil Uji Daya Terima } \\
\hline & & \multicolumn{2}{|c|}{ Habis } & \multicolumn{2}{|c|}{ Sisa $\leq \mathbf{5 0} \%$} & \multicolumn{2}{|c|}{ Sisa $>50 \%$} & \multirow{2}{*}{$\begin{array}{c}\text { Total } \\
\text { (n) }\end{array}$} \\
\hline & & $\mathbf{n}$ & $\%$ & $\mathbf{n}$ & $\%$ & $\mathbf{n}$ & $\%$ & \\
\hline 1 & Bubur latin & 4 & $50 \%$ & 3 & $38 \%$ & 1 & $13 \%$ & 8 \\
\hline 2 & Bubur Binjay & 0 & $0 \%$ & 0 & $0 \%$ & 1 & $100 \%$ & 1 \\
\hline 3 & Bujasay & 6 & $30 \%$ & 6 & $30 \%$ & 8 & $40 \%$ & 20 \\
\hline 4 & Bolu kukus buah sayur & 1 & $14 \%$ & 3 & $43 \%$ & 3 & $43 \%$ & 7 \\
\hline 5 & Green talam & 1 & $14 \%$ & 3 & $43 \%$ & 3 & $43 \%$ & 7 \\
\hline
\end{tabular}

Sumber: Data Diolah (2021) 
Tabel 7. Hasil Uji Daya Terima MP ASI Usia 9-12 bulan Berbahan Pangan Lokal

\begin{tabular}{|c|c|c|c|c|c|c|c|c|}
\hline \multirow[t]{3}{*}{ No } & \multirow[t]{3}{*}{ Menu } & \multicolumn{7}{|c|}{ Hasil Uji Daya Terima } \\
\hline & & \multicolumn{2}{|c|}{ Habis } & \multicolumn{2}{|c|}{ Sisa $\leq 50 \%$} & \multicolumn{2}{|c|}{ Sisa $>50 \%$} & \multirow{2}{*}{$\begin{array}{c}\text { Total } \\
\text { (n) }\end{array}$} \\
\hline & & $\mathbf{n}$ & $\%$ & $\mathbf{n}$ & $\%$ & $\mathbf{n}$ & $\%$ & \\
\hline 1 & $\begin{array}{l}\text { Menu } 1 \text { nasi, nugget lele, } \\
\text { mendol tempe, sayur kelor, } \\
\text { wortel }\end{array}$ & 5 & $50 \%$ & 3 & $30 \%$ & 2 & $20 \%$ & 10 \\
\hline 2 & Nasgultin & 3 & $30 \%$ & 4 & $40 \%$ & 3 & $30 \%$ & 10 \\
\hline 3 & Krupuk pangsit udang & 15 & $75 \%$ & 5 & $25 \%$ & 0 & $0 \%$ & 20 \\
\hline 4 & Puding roti pisang & 6 & $33 \%$ & 5 & $28 \%$ & 7 & $39 \%$ & 18 \\
\hline 5 & Stick labu kress & 10 & $50 \%$ & 5 & $25 \%$ & 5 & $25 \%$ & 20 \\
\hline
\end{tabular}

Sumber: Data Diolah (2021)

MP ASI untuk usia $>12$ bulan terdiri dari 2 makanan utama dan 3 makanan kudapan/selingan, dimana yang paling disukai balita usia $>12$ bulan adalah krupuk pangsit udang $75 \%$ habis terkonsumsi (15 panelis), dan yang paling tidak disukai adalah Nasgultin 30\% (3 panelis) dapat dilihat pada Tabel 7.

Pada umumnya MP ASI yang disukai adalah berupa kudapan/makanan selingan. Hal ini terjadi karena pada saat kunjungan ke Posyandu para panelis sudah disuapi dari rumah oleh ibunya, walaupun saat itu bukan waktunya jam makan. Sehingga saat uji daya terima beberapa panelis tidak mau mengkonsumsi MP ASI yang kami telah siapkan (masih utuh) dengan alasan baru makan dari rumah saat mau berangkat ke posyandu.

Pada anak usia 6-8 bulan adalah anak yang baru belajar untuk makan sehingga masih dalam rangka adaptasi dari menghisap ke mengunyah makanan. Akibatnya bayi butuh proses pengenalan baik tekstur, rasa maupun jenis makanan ini secara bertahap dari porsi yang sedikit 2-3 sendok makan setiap kali makan berlanjut menjadi lebih banyak sesuai dengan porsi yang dianjurkan (1/2 mangkok 250 ml). Pada uji daya terima MP ASI yang dilakukan dalam penelitian ini tidak melihat progres tersebut, tetapi hanya menyediakan porsi makanan maksimal (1/2 mangkok). Sehingga peneliti tidak bisa melihat hasil daya terima yang sesungguhnya.

Sedangkan untuk bayi usia 9-12 bulan jarang ada di posyandu lokasi penelitian sehingga hanya memperoleh 1 bayi saja. Setiap posyandu yang paling banyak adalah balita dengan usia diatas 12 bulan. Pada pemberian makanan lengkap anak usia $12-24$ bulan cenderung menghendaki makanan yang berkuah sehingga menu dengan sayur berkuah lebih disukai dari pada Nasi Gulung Patin yang tanpa kuah (kering) walaupun menarik tampilannya. Sebaliknya dengan kudapan, kudapan yang kering lebih disukai daripada kudapan yang basah. Kudapan yang kering dan krispy bagus sekali karena dapat merangsang pertumbuhan dan kekuatan gigi anak.

\section{SIMPULAN}

MP ASI yang dihasilkan adalah 10 resep MP ASI berupa makanan utama dan 5 resep makanan selingan. MP ASI dengan kalori tertinggi untuk usia 6-8 bulan terdapat pada Burikli ( 86,13 Kkal, 6,72 g protein dan Vitamin C 6,16 mg). Sedangkan untuk MP ASI usia 9-12 bulan kandungan kalori tertinggi pada Bujasay (118,7 kkal, protein 5,8 g dan vitamin C 3,52 mg ). Untuk MP ASI usia $>12$ bulan kandungan kalori tertinggi pada Nasi nugget Lele mendol 
tempe sayur kelor wortel ( 212 kkal, Anshori M, dkk, 2009, Buku Ajar protein 9,5 gram dan vitamin $\mathrm{C} 6,18 \mathrm{mg}$ ). MP ASI yang paling disukai untuk usia 6-8 bulan adalah Bubur Payam dan Bubur Batel, sedangkan untuk usia 9-12 bulan yang paling disukai adalah Bubur Latin dan Untuk usia $>12$ bulan yang paling disukai adalah kudapan krupuk pangsit udang. Adapun saran yang kami tekankan: (1) Untuk usia 6-8 bulan berikanlah MP ASI Burikli, usia 9-12 bulan berikanlah MP ASI Bubur Latin dan untuk usia $>12$ bulan berikanlah MP ASI berupa kudapan krupuk Pangsit udang. (2) Perlu penelitian lanjutan dengan menambahkan jenis bahan pangan lokal yang lainnya dan menggunakan uji efektifitas untuk menentukan MP ASI yang terbaik dari sisi kandungan gizi dan daya terimanya.

\section{DAFTAR PUSTAKA}

Adriani M, dkk, 2014, Peranan Gizi dalam Daur Kehidupan, Kencana Prenada Media Grup, Jakarta

Adriani M, dkk, 2012, Pengantar Gizi Masyarakat, Kencana Prenada Media Group, Jakarta

Almatsier, dkk, 2011, Gizi Seimbang dalam daur Kehidupan, PT Gramedia Pustaka Utama Jakarta Metodologi Penelitian Kuantitatif, Pusat Penerbitan dan Pencetakan Unair, Surabaya

Badan Penelitian dan Pengembangan Kesehatan. Riset Kesehatan Dasar (RISKESDAS). Kementerian Kesehatan Republik Indonesia. 2013

Deddy Muchtadi, 2009, Pengantar Ilmu Gizi, Alfabeta, Bandung

Persatuan Ahli Gizi Indonesia. Tabel Komposisi Pangan Indonesia. Jakarta: PT. Elex Media Komputindo; 2009. hal.2,40,42-45

Sitiatava Rizema Putra, 2013, Pengantar Ilmu Gizi dan Diet, D Medika, Jogjakarta

World Health Organizatiation. Infant and Young Child Feeding. [fact sheet; update July 2017) Available from: http://www.who.int/mediacentre/ factsheets/fs342/en/ 4. 